\title{
Pembelajaran Ekstrakurikuler Rebana Untuk Merangsang Kecerdasan Musikal Anak Usia Dini di RA PSM Kanigoro Kras Kediri
}

\author{
Irfatul Lailiyah \\ Program Magister PLAUD, Fakultas Tarbiyah dan Keguruan, Universitas Islam Negeri \\ Sunan Kalijaga Yogyakarta \\ E-mail: Irfatullailiyah@gmail.com
}

\begin{abstract}
ABSTRAK. Setiap anak yang labir tentu membawa potensi tertentu yang perlu dikembangkan melalui pembelajaran. Pembelajaran reguler waktunya sangat terbatas maka diperlukan pembelajaran ekstrakurikuler. Penelitian ini berusaha mengkaji bagaimana kualifikasi pembelajaran ekstrakurikuler rebana dapat merangsang kecerdasan musikal anak usia dini?. Bagaimana kualifikasi kekayaan kodrati yang dibawa anak sejak. labir itu akan berkembang secara lebih meningkat melalui pembelajaran ekstrakurikuler rebana?.Penelitian ini ditujukan untuk mendeskripsikan peran pembelajaran ekstrakurikuler rebana untuk merangsang kecerdasan musikal anak usia dini di Raudlatul Athfal PSM Kanigoro Kras Kediri. Metode penelitian yang digunakan adalah kualitatifdeskriptif, sehingga penyajiannya lebih detail dan mendalam. Data penelitian diperoleh dengan teknike observasi dan wawancara, uji validitasnya dengan triangulasi dan pemeriksaan sejawat. Sampel penelitian ini diperoleh dengan teknik, purposive snowball sampling difokuskan kepada tiga orang anak dan tiga orang pembimbing sebagai narasumber utama. Hasil penelitianinimenunjukkan babwa pembelajaran ekstrakurikuler rebana mempunyai kontribusi untuk merangsang kecerdasan musikal anak usia dini karena sifat pembelajarannya yang lebih menekankan kebebasan, berdasarkan piliban anak, adanya dukungan bakat dan frekwensi pembelajaran/pelatiban yang cukup.
\end{abstract}

Kata Kunci: Pembelajaran ekstrakurikuler, kecerdasan musical

ABSTRACT. Every child born certainly carries a certain potential that needs to be developed through learning. Regular time learning is very limited so extracurricular learning is needed. This research seeks to examine how tambourine extracurricular learning qualifications can stimulate musical intelligence in early childhood?. And how will the qualifications of natural wealth brought by the child from birth develop further through tambourine extracurricular learning? This study aimed to describe the role of tambourine extracurricular learning to stimulate musical intelligence of young children in Raudlatul Athfal PSM Kanigoro Kras Kediri. The research method used is qualitative-descriptive, so that the presentation is more detail and deepen. Research data obtained by observation and interview techniques, validity test with triangulation and colleague investigation. The sample of this study was obtained by purposive snowball sampling technique focused on three children and three mentors as the main resource persons. The results of this study indicate that tambourine extracurricular learning has a contribution to stimulate early childhood musical intelligence because the nature of learning is emphasizes more freedom, based on children's choices, the existence of talent support and the frequency of learning / training is sufficient.

Keyword: Extracurricular Learning, Musical Intelligence

\section{PENDAHULUAN}

Kadar kecerdasan setiap orang memiliki takaran yang berbeda-beda. Antara satu anak dengan anak yang lainnya, memiliki tingkat kecerdasan yang tidak sama, hal ihwal ini membuat 
setiap individu memiliki keunikannya masing-masing. Diskursus tentang kecerdasan seorang anak, telah banyak dikaji salah satunya oleh Aip Sanipudin (Sanipudin,2017: 9) yang meneliti tentang kecerdasan seorang anak dapat dilatih dengan cara sistem pembelajaran natural, yang berkaitan dengan kegiatan sehari-hari.Kajian tentang melatih kecerdasan Anak Usia Dini (AUD) juga dilakukan oleh, Siwi Widiastuti (Widiastuti, 2012: 59) bahwa, kecerdasan AUD dapat dilatih dengan strategi multiple intelligences dengan strategi pembelajaran berbasis budaya. Ada juga penelitian yang menyebutkan bahwa, kecerdasan kinestetik AUD dapat dilakukan dengan metode pembelajaran gerak dan lagu (Widhianawati, 2011: 220), dalam penelitian ini dikatakan bahwa, gerak dan lagu (bernyanyi) dapat mempengaruhi syaraf sehingga dapat membantu anak untuk lebih cerdas.

Tumbuh dan berkembangnya kecerdasan di dalam diri seorang anak oleh sebab itu, tidak bisa dilepaskan dari sistem pendidikan yang mereka akumulasi. Sistem dan lingkungan pendidikan, menjadi faktor fundamental yang menentukan terhadap tingkat kecerdasan seorang anak. Untuk menyebut dan mengklasifikasikan kecerdasan seorang anak, perlu indikator yang jelas, sebagai barometer untuk mengkategorikan kualifikasi kecerdasan mereka, sekaligus sebagai upaya melihat infiltrasi sistem pendidikan yang sudah disemai pada diri seorang anak, Musfiroh (Musfiroh, 2008: 1.1) mengemukakan bahwa, setiap anak memiliki tingkat kecerdasan dan indikator yang berbeda antara satu dengan yang lainnya. Fakta ini mendeskripsikan bahwa sesungguhnya, hakikat seorang anak adalah cerdas. Hanya saja, perbedaan kecerdasan mereka terletak pada level indikator kecerdasannya.Perbedaan tersebut disebabkan oleh berbagai faktor. Salahsatunya adalah kualitas stimulus yang diberikan pada seorang anak saat mereka masih berusia dini.

Statement di atas cukup untuk menyebutkan bahwa pada dasarnya, pendidikan anak usia dini memiliki peran vital, dan fungsinya sangat urgen untuk menstimulus kecerdasan seorang anak. Salah satu stimulus yang dapat dilakukan kepada seorang anak usia dini adalah yang berkaitan dengan seni, seperti seni musikal. Bakat seni tidak bisa dipelajari akan tetapi dilahirkan. Seni adalah sesuatu yang berkenaan dengan imajinasi, soul, dan kekuatan berpikir seseorang di dalam menangkap situasi di sekitar. Artinya bahwa, bakat seni tidak seperti kemampuan teknik lainnya yang bisa dengan mudah dipelajari dan digali dari seorang figure, pada seorang guru misalnya.Akan tetapi, bakat seni adalah keistimewaan yang dilahirkan dari intuisi, pembawaan yang terus digali dan dipupuk, seperti melalui latihan-latihan yang kuat dan konsisten.

Fakta di lapangan menunjukkan banyak anak-anak yang nampak memiliki bakat seni dengan berbagai genrenya. Hal itu nampak dari bagaimana cara anak menangkap pembelajaran seni di kelas, misalnya ketika anak-anak diberi pelajaran menyanyi dan atau menari.Mereka ada yang cepat menangkap pembelajaran sesuai dengan kualifikasi masing-masing, bagi yang suka menyanyi tentu cepat menangkap pembelajaran menyanyi begitu juga halnya yang suka menari juga demikian. Bahkan ada juga anak-anak yang nampak tidak begitu suka menyanyi atau menari namun mereka menyukai bermain benda-benda yang ada di kelas (jawa=kothekan).Kondisi ini menunjukkan adanya varians bakat seni bawaan pada anak, yang berbeda antara satu dengan yang lain. Fakta yang sedemikian menunjukkan adanya kecerdasan musikal pada anak, namun demikian masih memerlukan stimulus atau rangsangan yang intensif agar kecerdasan musikal itu lebih memiliki daya, gairah dan kualitas.

Raudlatul Athal PSMKanigoro Kras Kediri merupakan lembaga pendidikan anak usia dini yang menggunakan strategi pembelajaran ekstrakurikulerseni musik. Kegiatan bermain musik rebana sengaja dipilih oleh lembaga PAUD ini bukan tanpa alasan. Seni musikal rebana 
merupakan salah satu kegiatan seni yang mendorong sistem seni artistik musikal seorang anak. Memainkan rebana sebagai strategi pembelajaran ekstrakuriler PAUD merupakan langkah konkret yang diyakini dapat merangsang kecerdasan seorang anak melalui musik. Selain itu, pemilihan musik rebana sebagai kegiatan ekstrakurikuler memiliki tujuan yang sangat kompleks, selain ditujukan untuk memupuk rasa cinta kepada Nabi Muhammad. Juga sebagai upaya membuka simpul-simpul musikal yang ada pada diri anak. Simpul-simpul musikal yang ada pada diri anak usia dini, sangat penting sekali untuk dirangsang, agar kepekaan sekaligus kecermatan seorang anak semakin meningkat melalui latihan musikal rebana

Kecerdasan musikal pada anak memuat aspek-aspek yang banyak. Menurut Musfiroh (t.th: 5) kecerdasan musikal anak meliputi aspek: (1) cenderung cepat menghafal lagu-lagu dan bersemangat ketika diperkenalkan lagu kepadanya;(2) menikmati musik dan menggerak-gerakkan tubuhnya sesuai irama musik tersebut;(3) mengetuk-ngetukkan benda ke meja pada saat menulis atau menggambar.Mereka cenderung senang bermain alat musik atau bahkan bermusik denganbenda-benda tak terpakai (memancing kreativitas).(4) suka menyanyi, bersenandung, atau bersiul;(5) mudah mengenali suara-suara di sekitarnya seperti suara sepeda motor,burung, kucing, anjing (kepekaan);(6) dapat mengidentifikasi perbedaan jenis-jenis suara, seperti suarasuarasepeda motor dari merk yang berbeda, suara berbagai burung, suara kucinglapar dan berkelahi, suara beberapa guru dan temannya; (7) mudah mengenali suatu lagu hanya dengan mendengar nada-nada pertamalagu tersebut.Menurut Markam dalam Musfiroh (2008: 5.4) kecerdasan musikal memiliki lokasi di otak sebelah kanan (bemisfer kanan), khususnya lobus temporalis (daerah sekitar telinga). Lobus ini berkaitan dengan semua bagian serebrum (otak besar), serebelum (otak kecil), dan batang otak. Fungsi dari lobus ini memungkinkan seseorang dapat mengenali berbagai suara atau bunyi-bunyian nonverbal termasuk suara musik, bel, lonceng, dan suara binatang.

Kemampuan anak dalam hal kepekaan, kreativitas, dan kejelian sebagaimana di kemukakan di atas, menjadi indikator kecerdasanmusikal bawaan anak. Namun demikian, kekayaan kodrati itu perlu dipupuk, melalui sistem rangsangansejak dini agar kualifikasinya menjadi meningkat. Oleh sebab itu, penelitian ini akan mengkaji secara mendalam strategi pembelajaran ekstrakurikuler musik rebana di Raudhatul Athfal, apakah dapat membangun sistem rangsangan untuk meningkatkan kualifikasi kecerdasan anak.

Berdasar pada pemikiran yang dikemukakan di atas, peneliti akan melakukan kajian secara lebih mendalam, terutama berkaitan dengan permasalahan bagaimana kualifikasi pembelajaran ekstrakurikuler rebana dapat merangsang kecerdasan musikal anak usia dini?.Apakah kualifikasi kekayaan kodrati yang dibawa anak sejak lahir itu akan berkembang secara lebih meningkat melalui pembelajaranekstrakurikulerrebana?. Tujuan penelitian ini untuk mengetahui secara lebih detaildan mendalam tentang tingkat kualifikasi pembelajaran ekstrakurikuler rebana dapat merangsang kecerdasan musikal bagi anak usia dini. Penelitian sekaligus juga bertujuan untuk mengetahui apakah kekayaan kodrati yang dibawa anak sejak lahir itu akan berkembang secara signifikan melalui pembelajaran ekstrakurikuler rebana.

Teori behaviorisme yang dikembangkan oleh John Lockememandang anak seperti gelas kosong, kertas putih, atau tabularasi yaitu meja yang dilapisi lilin. Gelas kosong, kertas putih atau meja yang berlapis lilin tersebut dapat dibentuk sesuai dengan kehendak orang yang akan membuatnya (Nata, 2013: 72). Menurut behaviorisme ini pembelajaran atau pendidikan mutlak dapat menjadikan seseorang sesuai dengan kehendak atau tujuan pendidiknya. Pada sisi lain teori konvergensi mengemukakan bahwa pembentukan kepribadian seseorang bukan hanya ditentukan 
oleh pembawaan, kecakapan dan potensi yang dimiliki anak sejak lahir, melainkan juga dipengaruhi oleh lingkungan, yakni lingkungan keluarga, sekolah, masyarakat, suasana keagamaan, tradisi, budaya dan lain sebagainya (Nata, 2013: 73).

Islam mengajarkan bahwa manusia sejak lahir telah diberi potensi tertentu oleh Tuhan. "Maka apabila Aku telah menyempurnakan kejadiannya, dan telah meniupkan ke dalamnya ruh (ciptaan)Ku..." (QS. 15: 29), menurut Langgulung dalam Rahardjo (1989: 160)ayat ini menegaskan bahwa Tuhan memberi menusia berbagai potensi atau kemampuan yang berkaitan dengan sifat-sifat Tuhan.Dalam kata lain potensi yang diberikan Tuhan itu adalah fitrah, yang merupakan modal dasar bagi manusia agar dapat memakmurkan bumi ini. Juga merupakan potensi kodrati yang dimiliki manusia agar berkembang menuju kesempurna-an hidup (Suharto, 2014: 71). Dalam konteks ini tugas pendidikan atau pembelajaran adalah untuk mengubah (transform) potensi-potensi manusia menjadi kemampuan-kemampuan atau keterampilanketerampilan yang dapat dimanfaatkan manusia (Suharto,2014: 72).

Kajian ini memberikan gambaran jelas bahwa pembelajaran terlebih pembelajaran ekstrakurikuleryang berperan sebagai pembelajaran tambahan mempunyai nilai yang penting bagi upaya peningkatan potensi musikal AUD. Potensi musikal AUD akan semakin berkembang dengan baik melalui pembelajaran ekstrakurikuler rebana karena pada pembelajaran ini anak masih berada pada tahap pengembangan yang memerlukan support secara intensif, sementara support ini akan sangat terbatas sekali pada jam-jam pembelajaran reguler.

Hipotesa kajian ini adalah, kegiatan ekstrakurikuler musik rebana dapat merangsang kecerdasan musikal AUD. Kajian di dalam penelitian ini meliputi, hasil penelitian, pembahasan penelitian, dan simpulan dari penelitian. Harapan akan hasil penelitian ini bahwa pada kegiatanpembelajaranektrakurikuler rebana ini semakin intensif dan diimplementasikan dalam kegiatan ekstra dengan memberikan kebebasan pada anak, untuk menstimulus kecerdasan peserta didik, terutama kecerdasan musikalnya.

\section{METODE}

Penelitian ini menggunakan metode kualitatif-deskriptif yaitu, penelitian yang memusatkan pada kegiatan ontologis, lalu kemudian dinarasikan dengan detail. Data yang dikumpulkan terutama berupa data informan, kalimat atau gambar yang memiliki makna dan mampu memacu timbulnya pemahaman yang lebih nyata daripada sekedar angka atau frekuensi. Peneliti menekankan catatan dengan deskripsi kalimat yang rinci, lengkap, mendalam yang menggambarkan situasi yang sebenarnya guna mendukung penyajian data. Oleh sebab itu penelitian kualitatif secara umum sering disebut sebagai pendekatan kualitatif deskriptif. Peneliti berusaha menganalisis data dalam berbagai nuansa sesuai bentuk aslinya seperti pada waktu dicatat atau dikumpulkan (Nugrahani, 2014: 96). Untuk menguji validitas data maka peneliti perlu melakukan perpanjangan kehadiran yaitu dengan melakukan perpanjangan masa observasi, wawancara guna memperoleh data yang valid dari lokasi penelitian dengan menambah yang kurang dan meningkatkan variasinya. Triangulasi, peneliti berusaha menguji data dengan mengkaji melalui beberapa sumber dan metode serta peneliti mengadakan pengecekan dengan teori yang dikemukakan oleh para ahli. Dan pemeriksaan sejawat dalam hal ini peneliti berusaha menguji validitas data melalui diskusi dengan beberapa teman, kolega, terutama teman peneliti satu jurusan. Maka apabila pada data-data tersebut belum ditemukan jawaban yang jelas peneliti mengadakan diskusi dengan pembimbing untuk memberikan bantuan pemecahan masalah. 
Penelitian kualitatif menurut Sugiyono (2015: 15) adalah "metode penelitian yang berlandaskan pada filsafat postpositivisme, digunakan untuk meneliti pada kondisi objek yang alamiah, (sebagai lawannya adalah eksperimen) dimana peneliti adalah sebagai instrument kunci, pengambilan sampelsebagai sumber data dilakukan secara purposive dan snowball. Populasi penelitian ini adalah AUD yang mengikuti pembelajaran ekstrakurikuler rebana dengan jumlah 21 anak dengan tiga orang guru pendamping. Sampel sebagai sumber data penelitian ini adalah tiga orang anak usia dini dan tiga orang guru pendamping yang setiap kali latihan atau tampil selalu mendampinginya. Tekniknya, berdasar keterangan yang jelas dari sampel penelitian selaku sumber data selanjutnya dikonfirmasi pada sumber lain yang berhubungan dengan permasalahan penelitian sampai mencapai titik jenuh sehingga diperoleh data yang mencukupi, valid, variatif dan terpercaya.

Teknik pengumpulan data dan pengembangan instrumen; dan teknik pengumpulan dengan trianggulasi (gabungan), melalui observasi, wawancara, dan catatan di lapangan melalui daftar chek list. Yang kemudian dilakukan analisa data berupa reduksi data, penyajian data dan penarikan kesimpulan. Pada proses analisis data, penelitian ini menggunakan model analisis Miles dan Huberman sebagaimana dikutip oleh Sugiyono (2015: 337) yang digambarkan langkahnya dalam gambar sebagai berikut:

\section{Gambar. 1}

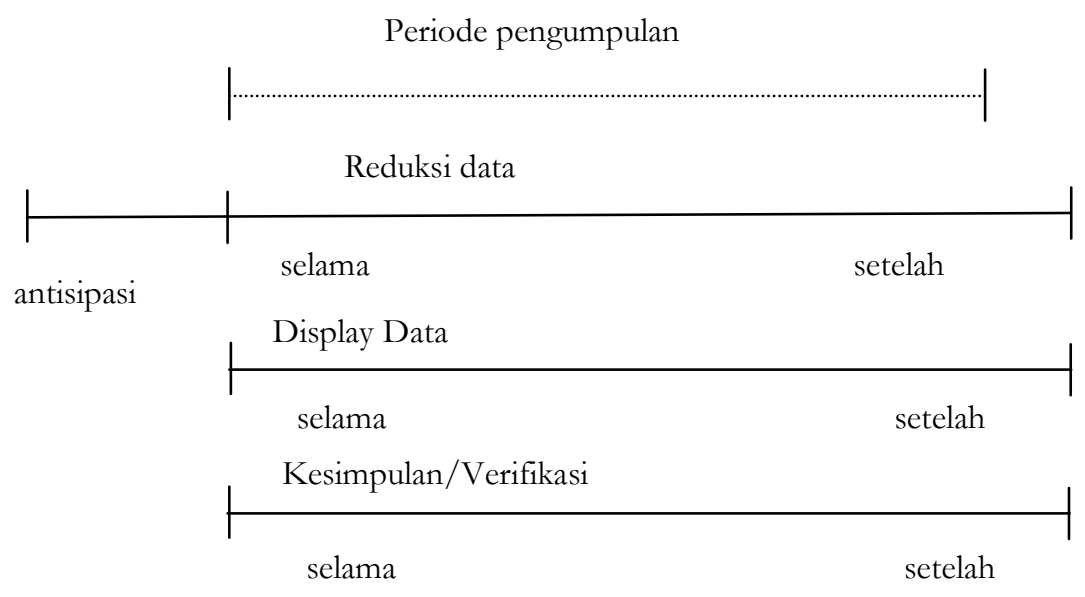

Pada awalnya peneliti mengumpulkan data dari lapangan melalui observasi dan wawancara. Setelah data terkumpul selanjutnya data-data tersebut dilakukan reduksi, karena data yang masuk cukup banyak selanjutnya dicatat dan dirinci dengan memilih hal-hal yang pokok, memfokuskan pada hal-hal yang penting dicari tema dan polanya serta dibuang hal-hal yang tidak penting. Setelah direduksi selanjutnya mendisplay data agar mudah dipahami yang dikemukakan melalui uraian singkat atau yang lainnya. Setelah jelas selanjutnya dilakukan pengambilan kesimpulan (conclusion) dan verifikasi.

Analisis data ini dilakukan pada saat pengumpulan data berlangsung, dan setelah selesai pengumpulan data pada pereode tertentu. Pada saat peneliti melakukan wawancara, peneliti sudah melakukan analisis terhadap jawaban yang diwawancarai. Bila memuaskan, maka peneliti akan melanjutkan pertanyaan berikutnya, sampai pada tahap tertentu sehingga diperoleh data yang cukup kredibel. 


\section{Reduksi Data}

Reduksi data merupakan kegiatan merangkum, dan memilih hal-hal pokok. Fokus kepada hal-hal yang dipentingkan, dicari polanya serta membuang bagian-bagian yang tidak diperlukan lagi. Pada penelitian ini, akan dilakukan pemeriksaan kembali data-data yang telah dikumpulkan baik data dari observasi, wawancara,dan dokumentasi maupun catatan di lapangan melalui daftar chek list. Data-data penelitian yang telah dikumpulkan akan direduksi untuk memberikan suatu gambaran yang jelas mengenai hasil-hasil penelitian yang telah dilakukan.

Kegiatan penelitian pada bagian reduksi data ini adalah mengumpulkan data penelitian yang diperoleh dari lapangan melalui observasi dan wawancara maupun dokumentasi. Peneliti memilih dan memilah data-data tersebut untuk dicari yang sesuai dengan tema penelitian ini. Setelah ditemukan data penelitian yang sesuai dengan tujuan penelitian selanjutnya didisplay atau digambarkan dalam suatu narasi yang jelas menggambarkan situasi anak yang mengikuti pembelajaran ekstrakurikuler rebana.

\section{Penyajian Data}

Penyajian data penelitian dimaksudkan untuk menyusun informasi yang dikumpulkan untuk mempermudah peneliti dalam menganalisis data penelitian. Melalui penyajian data tersebut, hasil penelitian akan lebih mudah untuk dipahami dan dimengerti pembaca. Penyajian data di dalam penelitian ini, dilakukan dengan cara menarasikan data yang sudah digali di lapangan, dengan deskripsi secara komprehensif dan kritis, sebagai upaya untuk melihat permasalahan kajian penelitian ini secara lebih mendalam.

Peneliti berusaha menyajikan hasil penelitian dalam sebuah narasi yang mudah dipahami oleh pembaca. Narasi data juga dikemukakan dalam bentuk chart hasil penelitian untuk menunjukkan adanya hubungan yang sinkron antara data dengan permasalahan penelitian.

\section{Pengambilan Kesimpulan}

Penarikan kesimpulan penelitian dilakukan setelah analisis dan pembahasan yang diharapkan merupakan temuan baru. Kesimpulan penelitian ini adalah konfirmasi terhadap hipotesa awal di dalam penelitian ini. simpulan ini sekaligus akan memberikan jawaban terhadap permasalahan penelitian sesuai dengan tema penelitian ini.

\section{HASIL DAN PEMBAHASAN}

\section{Hasil Penelitian}

Penelitian ini dilaksanakan di Raudlatul Athfal PSM Kanigoro Kras Kediri. Peneliti mengadakan wawancara dengan guru Pembina pembelajaran ekstrakurikuler Rebana, mengadakan observasi dengan pedoman observasi checklist dan pedoman wawancara. Hasil wawancara yang dilakukan terhadap guru Pembina. Berdasarkan hasil temuan, diperoleh 21 anak yang tergabung dalam ekstrakurikuler Rebana, sementara yang lain mengikuti kegiatan ekstrakurikuler jenis lainnya.

Pada lembaga ini anak diberi keleluasaan memilih jenis ekstrakurikuler yang ingin diikuti tanpa harus dipaksa. Anak mengambil suatu jenis tertentu berdasarkan keinginan dan pertimbangan orang tuanya. Hasil temuan ini didapatkan melalui observasi secara langsung terhadap anak yang sedang melakukan latihan shalawatan atau rebana dan wawancara terhadap seorang guru pendamping. 
Para orang tua berkeinginan agar anak-anak pada saatnyamemiliki kecintaan kepada Nabi dan memiliki karakter yang kuat pula dalam seni musik berbasis Islam. FT seorang guru pendamping menjelaskan bahwa, para orang tua berkeinginan anak-anaknya memiliki rasa cinta yang baik kepada Nabi, oleh karena itu merekamemasukkan anaknya dalam kegiatan ekstrakurikuler rebana. Tujuan dan harapan mereka adalah, agar anak-anak mereka giat didalam bershalawat kepada nabi. Menanamkan kebiasaan shalawatmenurut mereka sangat sulit, kecuali melalui kegiatan-kegiatan yang berbasis Islam dengan iringan musik Islami seperti halnya rebana, selanjutnya FT mengemukakan:

Para orang tua berkeinginan kuat agar anak-anaknya itu terbiasa untuk bershalawat kepada Nabi, maka mereka memilih ekstrakurikuler rebana. Karena dengan rebana selain anak-anak itu terbiasa bershalawat pada Nabi sekaligus mereka bisa memperkuat kemampuannya dalam seni Islam. Keinginan orang tua untuk mengasah bakat senianak-anaknya sekaligus bakatnya dalam bermain musik sejak dini agar karakter anaknya mudah terbentuk.

Hasil penelitian menunjukkan bahwa pilihan ekstrakurikuler rebana ini didominasi pilihan anak sendiri, mencapai $52,3 \%$, berdasar pilihan orang tua $14,2 \%$ dan berdasarkan pilihan anak didorong oleh orang tua 33,3\%. Berkaitan dengan hal ini peneliti tidak menemukan hasil adanya ikut-ikutan dengan teman. Gambaran pilihan ini dapat dikemukakan dalam bentuk Chart sebagai berikut:

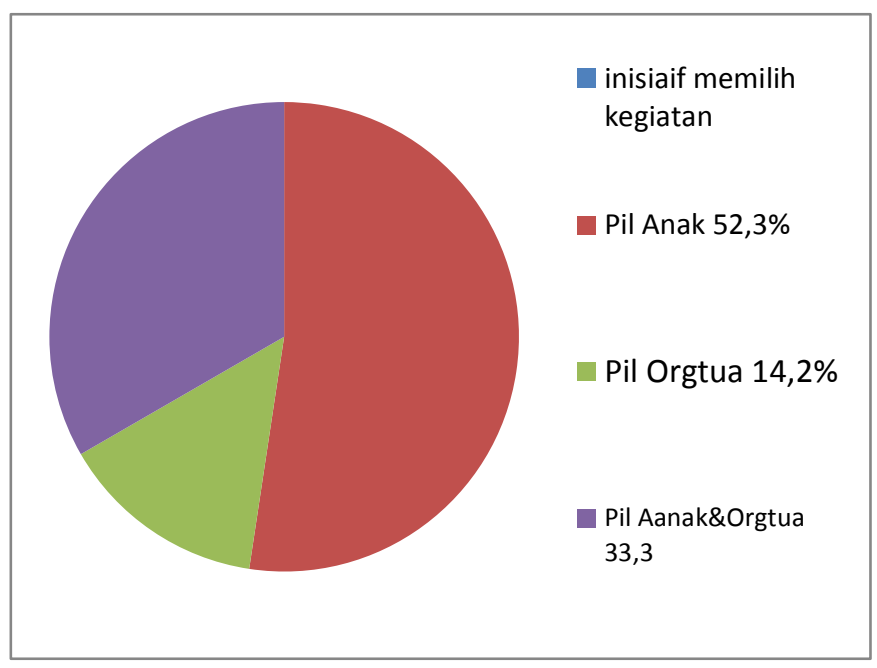

SL seorang wali murid mengemukakan pendapatnya bahwa melalui kegiatan ekstra rebana ini, anaknya di rumah semakin sering bershalawat bahkan jika mereka bersenandung ketika bermain juga lebih sering menyenandungkan shalawat, berkaitan dengan ini SL mengemukakan:

Setelah anak-anak ini ikutan dalam ekstra rebana, kebiasaannya di rumah juga bershalawat. Saya kaget,daya tangkapnya terhadap musik itu juga bertambah, misalnya ada lagu, bukan rebana, tetapi melantunkan senandung shalawat gitu ia langsung bisa menangkap dan menyesuaikan diri dengan musiknya, walau ada beberapa yang kurang pas, saya rasa semua itu soal waktu saja.

Dalam observasi yang dilaksanakan peneliti, terlihat dengan jelas bahwa, anak-anak ketika latihan shalawatan atau rebana begitu menikmati dan menghayati. Sekalipun suara mereka terkadang tidak terorganisir dengan baik, namun atas bimbingan para Pembina, nampak dengan jelas adanya keteraturan irama. Terdapat seorang anak, RK namanya, ia begitu sudah tertata 
nada-nadanya dalam melantunkan shalawat nabi. Setelah peneliti mencari tahu keberadaan dia, ternyata ia anak seorang pelantun shalawat pada sebuah grup shalawatan di kampungnya. RK jika dibandingkan dengan anak yang lain, memiliki kemampuan yang lebih. Terutama di dalam kegiatan ekstrakurikuler rebana di Raudhatul Athfal. Itu artinya, ketika seorang anak sering melakukan kegiatan bermusik rebana, kecerdasan mereka semakin terbangun. Hal itu terlihat pada diri RK, selain mendapat kegiatan bermusik rebana di sekolah, lingkungannya juga mendukung dan merangsang diri RK untuk terus bersholawat. Membuatnya lebih akrab dan lebih rutin mendapat rangsangan melalui musik rebana. Terlihat pada diri RK, inisiatif diri dan tindakannya ketika berada di dalam kelompok ekstrakurikuler rebana. Inesiatif diri RK untuk melakukan tindakan dibandingkan anggota yang lain di dalam kegiatan ekstrakurikuler, seperti misalnya berusaha membuat nada dan irama sholawat rendah dan tinggi, agar lebih teratur dengan nada kelompok, mengindikasikan bahwa RK sangat peka, responsif, dan kreatif. RK oleh karena itu, menjadi bukti bahwa infiltrasi kegiatan ekstrakurikuler musik rebana sangat berpengaruh dalam merangsang kecerdasan anak.

Dari 21 anak itu, tidak semuanya memegang rebana, sebagian memegang rebana sebagian lainnya menjadi vocalisnya. Kembali menurut FT bahwa, anak-anak itu mempunyai kepekaan yang berbeda-beda terhadap musik, ada yang lebih dominan dalam vocal, dan ada yang lebih peka dalam bermain musik. Namun demikian,variasi itu menjadi suatu bagian penting dari kecerdasan bermusik. Kepekaan terhadap bunyi (musik) atau kelihaian di dalam memadupadankan irama dan nada sholawat, menjadi indikator bahwa, seorang anak itu cerdas atau tidak. Anggota ekstrakurikulerrebana, memiliki kepekaan terhadap seni musik rebana, baik sebagai vokalis ataupun pemain musik. Jadi bisa disimpulkan bahwa, kecerdasan anggota ekstrakurikuler rebana di Raudhatul Athfal terbentuk dengan baik melalui kegiatan kesenian musik rebana.

Berdasarkan hasil observasi peneliti, nampak anak-anak yang menjadi vocalis demikian menikmati suara musik dan ia terus mengimbanginya dengan melantunkan nada sholawat. Namun demikian, ada beberapa anak yang juga bisa melakukan dua kegiatan sekaligus, yaitu bermain musik rebana sekaligus menyenandungkan sholawat.Memang belum terlihat begitu mahir dalam memainkan rebana, tetapi tabuhan mereka menunjukkan kemampuan dasar bermain musik rebana telah mereka kuasai. Bahkan pada saat peneliti datang dengan menyetel shalawatan melalui ponsel, mereka semuanya saling sahut untuk menirukan shalawatan dari ponsel peneliti. Menurut keterangan para wali murid, anak-anaknya memang jika mendengarkan shalawatan di telfon seluler atau di TV juga selalu menirukan bahkan menurutnya lebih keras dari suara yang didengarnya. Fakta ini menjelaskan bahwa, di dalam diri anak sudah tertanam seni musikal rebana, sekaligus membentuk diri anak itu secara tidak langsung sehingga ketika mereka mendengarkan lagu atau musik yang seirama mereka akan meresponnya. Harapan menumbuhkan cinta kepada nabi Muhammad SAW. melalui kegiatan ekstrakurikuler musik rebana oleh sebab itu, berjalan sesuai dengan rencana awal lembaga Raudhtul Athfal, yang ingin menciptakan anak didik yang cinta kepada Nabi dan memiliki kecerdasan musikal yang bagus.

Salah satu Pembina kegiatan ekstrakurikuler musik rebana SQ, mengemukakan bahwa melalui rebana kecenderungan anak dalam bermain musik semakin meningkat. Pernyataan itu artinya, kegiatan seni musik rebana mendorong anak didik pada hal-hal yang positif. Ekstrakurikuler rebana ini mampu menggugah gairah anak-anak dalam bermusik, karena setelah anak-anak ikut rebana terlihat mereka begitusenang menikmati musik, terutama jenis musik yang bergenre shalawat. 
Dengan berlatih rebana seperti ini, anak-anak nantinya akan terangsang gairah bermusiknya. Memang musik itu ada hubungannya dengan bakat, sekalipun demikian bukan berarti tidak bisa dipelajari. Berlatih musik bagi yang berbakat berarti mempertajam, bagi yang tidak berbakat berarti berusaha menjadi bisa. Maka ekstrakurikulerrebana ini bisa berperan untuk mempertajam dan bisa berperan untuk pembelajaran, yang jelas akan sangat membantu sekali untuk merangsang kecerdasan musikal anak-anaknya.

Peneliti melihat anak-anak di sekolah yang banyak mendendangkan lagu shalawat,sambil mengetuk-ngetuk meja belajar sambil bersholawat. Kebiasaan itu menunjukkan bahwa, ketika kecerdasan anak-anak didik dirangsang, terutama melalui strategi seni musik rebana, meskipun dengan alat seadanya mereka bisa bersholawat. Memilih pensil sebagai pengetuk bangku untuk menimbulkan bunyi pengiring sholawat ketika tidak sedang dalam kelas, menjadikan kreativitas anak semakin terlatih.

KJ juga merupakan bagian dari pembina, Ia menuturkan bahwa dengan adanya latihan rebana, anak-anak memiliki rangsangan musikal yang baik. Ia akan tertarik dan merespon apabila ada suara-suara yang bernada indah. Terlebih ketika mendengar alunan sholawat, anak akan menjadi terpantik daya kecerdasannya, mulai dari ingatan hingga tindakan yang berwujud sholawat. Menurutnya dukungan orang tua mempunyai peranan penting untuk meningkatkan kecerdasan musikal anak.Anak yang lahir dan besar di lingkungan orang tua yang memiliki kegemaran bersholawat seperti RK, sangat berpengaruh terhadap ketertarikan dan respon musik.Asumsi ini dibuktikan menurut KJ, apabila orang tuanya itu gemar musik anaknya juga bagus responnya terhadap musik pada kegiatan pembelajaran. Ketika peneliti bertanya kepada anak-anak, respon mereka menunjukkan kesenangan terhadap musik. Peneliti bisa menangkap kesan bahwa,anak-anak senang dengan pembelajaran ekstrakurikuler rebana, karena bisa belajar musik rebana dan bernyanyi. Ketertarikan anak-anak pada kegiatan ekstrakurikuler musik rebana, dalam konteks Raudatul Athfal, tidak bisa dilepaskan dari strategi pembelajaran yang diambil oleh pihak lembaga. Hal ini bisa dilihat dari antusiasme anak-anak dalam kegiatan ekstrakurikuler ini, situasi yang menunjukkan bahwa pendekatan pembelajaran ini diimplementasi-kan dengan tepat dan benar oleh guru, sehingga anak-anak menjadi semangat, ceria, dan menikmati kegiatan itu.

Gambaran hasil penelitian ini dapat dikemukakan dalam bentuk bagan sebagai berikut:

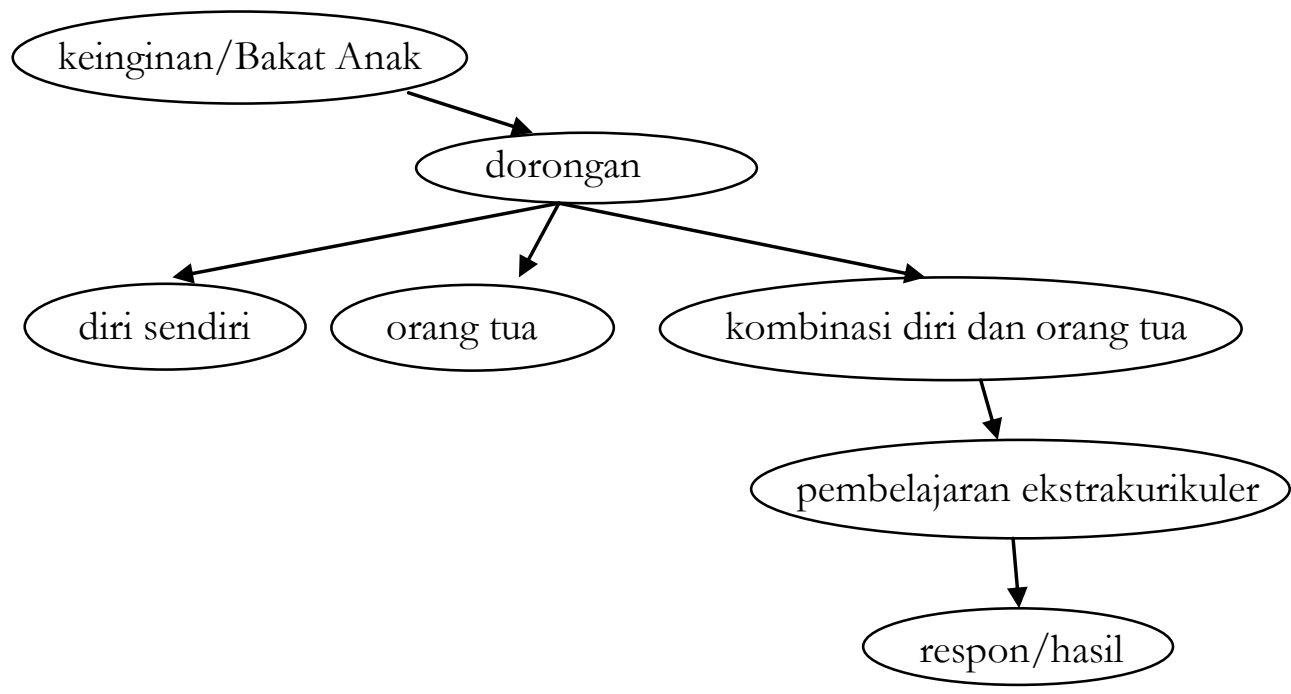




\section{Pembahasan}

Penelitianini dilaksanakan pada tanggal 13 September 2019 di Raudhatul Athfal PSM Kanigoro Kras, Kediri. Pada setiap proses penelitian yang sudah dilakukan, peneliti menemukan semangat progresif dan inovatif dari sistem pendidikan kita hari ini. Fakta ini bisa merupakan implikasi sistem pendidikan yang telah diatur di dalam undang-undang pendidikan nomor 20 Tahun 2003 tentang Sistem Pendidikan Nasional. Legitimasi formal undang-undang ini menjadi semangat baru untuk merangsang kecerdasan anak, khususnya oleh lembaga-lembaga Pendidikan Anak Usia Dini (PAUD), menjadikan kreativitas dan kecerdasan anak didik sebagai prioritas dan tanggung jawab seorang guru. Berangkat dari semangat itulah kemudian, akhirnya dari kota hingga kampung-kampung bahkan,banyak bermunculan Taman Kanak-kanak, dengan visi dan inovasi yang progresif untuk membantu kercerdasan seorang anak tumbuh maksimal, seperti yang dilakukan oleh lembaga Pendidikan Anak Usia Dini (PAUD) Raudhatul Athfal melalui kegiatan ekstrakurikuler musik rebana.

Pembelajaranekstrakurikuler pada dasarnya merupakan strategi sistem pendidikan, guna memberikan pembelajaran tambahan kepada anak, terutama pelajaran-pelajaran yang tidak bisa diberikan di dalam kelas. Selain itu, pembelajaran tambahan ini juga dimaksudkan untuk mengisi waktu kosong anak-anak agar mereka selalu melakukan aktivitas positif yang dapat menunjang terhadap perkembangan kecerdasannya. Seperti kegiatan bermusik sambil bersholawat, membuat anak-anak bermain sekaligus belajar. Suatu strategi yang tepat untuk membuat anak-anak tumbuh positif. Dari kegiatan pembelajaran seperti ini,anak diajarkan time management, membuat anak mengerti kapan dia harus belajar, bermain, atau waktu belajar sambil bermain, seperti kegiatan ekstrakurikuler ini, anak tetap belajar setelah kelas selesai, dengan kondisi yang tidak tegang dan tetap bisa memproduksi nilai-nilai positif.

Setiap orang lahir dengan kecerdasan masing-masing, hanya saja kecerdasan seseorang tidak akan berkembang apabila tidak mendapat rangsangan, agar kecerdasan itu bermanifestasi menjadi potensi diri. Proses belajar di dalam kelas adalah bagian dari upaya merangsang kecerdasan, agar potensi itubisa berkembang, sama halnya dengan kecerdasan musikal. Menurut Amstrong sebagaimana dikutip Musfiroh (2003: 3) "Kecerdasan musik merupakan kecerdasan yang paling dini muncul. Kecerdasan ini sudah tampak ketika anak-anak masih sangat kecil. Oleh kerena itu, ketika kecerdasan musikal anak dirangsang dari sejak dini, potensi itu akan semakin tumbuh berkembang menjadi lebih baik, dan tidak hanya berpengaruh pada seni bermusiknya saja, tetapi pada kreativitas dirinya secara umum. Demikian juga sikap manis dan hangat para pengasuh dan guru, di dalam memberikan pendidikan baik di dalam kelas atau pun di dalam kegiatan ekstrakurikuler, sangat menentukan terhadap kecerdasan seorang anak didik (Musfiroh, 2003:3).

Melalui pembelajaran ekstrakurikuler musik rebana adalah strategi tepat untuk merangsang kecerdasan musikal anak.Selain kegiatan ini menyenangkan, proses pembelajaran ekstrakurikuler memberikan situasi tidak formal, membuat anak-anak lebih bebas untuk berekspresi. Pembelajaran ekstrakurikuler disampaikan dengan teknik yang jauh lebih santai, sehingga anak-anak bisa menikmati dengan baik sambil bermain-main, merasa bebas dan tidak terkekang. Tuntutan untuk konsentrasi tidak seketat pada pembelajaran di kelas, pun juga dengan tuntutan hasil kegiatan, tidak seketat di dalam kelas. Oleh sebab itulah,pembelajaran ekstrakurikuler cenderung lebih mudah dinikmati oleh anak-anak.

Dari sini dapat dikemukakan bahwa, faktor teknik penyampaian dalam pembelajaran, pada pembelajaranekstrakurikuler rebana,mudah merangsang anak-anak, baik dalam hal 
memberikan respon atau pun kreativitas dalam belajar.Sehingga kecerdasan anak jauh akan lebih mudah terangsang. Selain itu, teknik pembelajaran ini akan mudah membekas pada diri seorang anak, sehingga mereka akan cenderung mengaplikasikannya di dalam kehidupan sehari-hari. Ini artinya bahwa faktor "situasi pembelajaran"memberikan kesan yang lebih baik apabila menggunakan seni seperti rebana, kegiatan yang dapat mendorong kecerdasan musikal anak.

Selain faktor situasi pembelajaran,faktor ketepatan pilihan, menjadi sangat urgen di dalam melihat kecerdasan dan potensi anak. Dapat dilihat, jumlah anak yang ada di Raudlatul Athfal PSM Kanigoro, hanya 21 anak yang memilih ekstrakurikuler rebana. Pilihan kegiatan ekstrakurikuler oleh karena itu, menjadi sangat fundamental dan menentukan terhadap tumbuh dan berkembangnya anak, terutama terhadap pertumbuhan kecerdasannya.Ketika seorang anak merasa tepat dengan pilihannya, maka semangatnya untuk merespon proses pembelajaran itu akan menjadi semakin baik. Hal ini terlihat dari respon anak terhadap ekstrakurikuler musik rebana sebagai proses pembelajaran yang menentukan terhadap perkembangan kecerdasannya.

Faktor bakat atau bawaan juga tidak bisa dipungkiri, memiliki peranan penting dalam merespon pembelajaran musikal khususnya. Ini artinya bahwa kecerdasan musikal seorang anak juga berkaitan dengan bawaannya sejak lahir. Namun demikian, bukan berarti kecerdasan musikal setiap orang tidak bisa dirangsang, karena beberapa anak yang adatidak semuanya berbakat, akan tetapi mereka bisa dan mampu karena mendapat rangsangan dan latihan, seperti melalui pembelajaran ekstrakurikuler musik rebana yang terbukti mampu membuka simpul-simpul kecerdasan musikal anak.

Hasil penelitian sebagaimana paparan di atas menunjukkan adanya peran pembelajaran ekstrakurikuleruntuk merangsang kecerdasan musical anak usia dini. Hal mana ditunjukkan oleh kenyataan bahwa anak-anak banyak yang memberikan respon positif terhadap pembelajaran ekstrakurikulerrebanamelalui kemampuannya yang lebih meningkat terhadap rangsangan musik. Daya tangkap anak yang responsif terhadap musik setelah mengikuti pembelajaran ekstrakurikuler rebana menunjukkan gairahnya semakin meningkat. Gairah anak yang semakin meningkat menunjukkan pada terbukanya simpul-simpul bermusik yang ada pada dirinya baik yang berbasis pada bakat atau pembawaan dan atau dari anak yang tidak berbakat sama sekali. Dengan demikian pembelajaran ekstrakurikulerdapat berperan untuk memberikan rangsangan terhadap bakat musik yang ada pada anak.

Ketika gairah bermusik anak-anak yang tidak berpotensi tinggi bakat musiknya bisa dipacu oleh pembelajaran ekstrakurikuler rebana, maka mafhum mukhalafahnya anak-anak yang mempunyai bakat atau berpembawaan musik cukup kuat justru akan lebih tinggi potensi untuk dirangsang gairahnya. Hal ini tentu wajar saja karena pada dasarnya pembelajaran itu untuk memberikan rangsangan-rangsangan (stimulus) terhadap anak agar potensi yang dibawanya sejak lahir bisa lebih baik kualifikasinya. Sebagaimana telah dikemukakan di atas bahwa pada dasarnya setiap orang itu memiliki pembawaan berupa potensi-potensi (fitrah) tertentu, hanya lingkungan atau pendidikanlah yang bisa menjadikan potensi-potensi itu menjadi potensial.

\section{SIMPULAN}

Pembelajaran ekstrakurikuler rebana banyak memberikan kontribusi untuk merangsang kecerdasan musikal anak. Efektivitas rangsangan musikal melalui pembelajaran ekstrakurikuler rebana inididukung oleh banyak faktor:pertama, faktor situasi pembelajaran yang lebih santai dibandingkan dengan pembelajaran formal di kelas. Kondisi ini membuat situasi rileks pada anakdalam mengikuti proses pembelajaran. Kedua faktor pilihan, pilihan anak dalam pembelajaran 
ekstrakurikuler rebana,berperanpenting di dalam mengorganisasikan antara minatdan sistem pembelajaran ekstrakurikuler musik rebana, dengan demikian anak akan merasakan kesesuaian antara materi pembelajaran dengan keinginan. Ketiga bakat, kecerdasan musikal anak akan nampak jelas karena adanya bakat yang sudah ada pada dirinya, ketika baka dipupuk dengan maksimal akan menjadi potensi diri seorang anak. Keempat, faktor frekuensi latihan dalam pembelajaran ekstrakurikuler rebana, memiliki kontribusi membuka kecerdasan musikal anak. Latihan bermusik di dalam kegiatan ekstrakurikuler rebana, membuat kecerdasan seorang anak mendapat rangsangan yang maksimal.

\section{REFERENSI}

Departemen Agama republic Indonesia, 2000, Al-Qur'an dan Terjemahnya, Surabaya, UD Mekar. Nata, Abudin, 2013, Pemikiran Pendidikan Islam \& Barat, Jakarta, PT RajaGrafindo Persada.

Nugrahani, Farida. 2014. Metode Penelitian Kualitatif dalam Penelitian Pendidikan Bahasa, Surakarta; tp. Musfiroh, Tadzkirotun Multiple Intelligences, PAUD lemlit-UNY, PBSI FBS-UNY

------, 2003. Kecerdasan Musikal dan Stimulasinya pada Anak usia 0-5 Tabun, Yogyakarta: Makalah disampaikan di hadapan pendidik dan pengasuh Taman Penitipan Anak dan Kelompok Bermain Kamis, 7 Agustus, di BPKB.

------, 2008. Pengembangan Kecerdasan Majemuk. Jakarta: Universitas Terbuka.

Rahardjo, M. Dawam, 1989, Islam Indonesia Menatap Masa Depan, Jakarta, P3M.

Sugiyono. 2015. Metode Penelitian Pendidikan Pendekata Kuantitatif, Kualitatif, dan R \& D, Bandung: Alfabeta.

Suharto, Toto, 2014, Filsafat pendidikan Islam Menguatkan Epistimologi Islam dalam Pendidikan, Yogyakarta, Ar-Ruzz Media.

Undang-Undang Republik Indonesia Nomor 20 Tahun 2003 tentang Sistem Pndidikan Nasional (Sisdiknas), Bandung: Citra Umbara.

Saripudin, Aip. Strategi Pengembangan Kecerdasan Naturalis Pada Anak Usia Dini (AWLADY: Jurnal Pendidikan Anak, Vol.3, No.1, Maret 2017)

Widhiawati, Nana. Pengaruh Pembelajaran Gerak dan Lagu Dalam Meningkatkan Kecerdasan Musikal Dan Kecerdasan Kinestetik. Anak Usia Dini: Studi Eksprerimen Kuasi Pada Anak Kelompok Bermain Mandiri SKB Sumedang (Academia.edu, Edisi Khusus, no.2, Agustus, ISSN. 1412565X: 2011)

Widiastuti, Siwi. Pembelajaran Proyek Berbasis Budaya Lokal Untuk Menstimulasi Kecerdasan Majemuk Anak Usia Dini(Jurnal Pendidikan Anak, Vol.1, Edisi.1, Juni 2012). 